\title{
DETECTION OF MULTI DRUG RESISTANT FOOD BORN BACTERIA IN READY TO EAT CHICKEN MEAT
}

\author{
ZEINAB AHMED ${ }^{1}$ AND SHIMAA EL- NAGAR ${ }^{2}$ \\ ${ }^{1}$ Reference Laboratory for Veterinary Quality Control on Poultry Production (RLQP), Animal \\ Health Research Institute, Agricultural Research Center, Luxor, Egypt., Dokki, Giza \\ ${ }^{2}$ Reference Laboratory for Veterinary Quality Control on \\ Poultry Production (RLQP), Animal Health Research Institute, Agricultural Research Center, Luxor, Egypt
}

Received: 19 December 2020; Accepted: 20 January 2021

\begin{abstract}
One hundred fifty samples were read to eat chicken meaty collected from different restaurants in Luxor city to evaluate bacteriological quality RTE chicken meat. The mean values of $A P C$, Coliform, Staphylococcus counts, Anaerobic count, Yeast count, Mould count (cfu /g). $1.36 \times 10^{4} \pm 2.94 \times 10^{3} \& 8.42 \times 10^{2} \pm 3.90 \times 10^{2}, 4.67 \pm 1.15 \& 1.00 \pm 0.73 \& 7.67 \pm 2.23,2.67 \pm 1.26$ to chicken shawirma without addition, $5.58 \times 10^{3} \pm 1.16 \times 10^{3} \& 3.34 \times 10^{2} \pm 9.82 \times 10 \& 2.33$ $\pm 1.24 \& 1.00 \pm 0.75 \& 8.33 \pm 2.40 \& 2.67 \pm 1.26$ for chicken burger without addition and $4.62 \times 10^{3} \pm 7.42 \times 10^{2} \& 1.53 \times 10^{2} \pm 4.85 \times 10 \& 1.33 \pm 0.79 \& 3.00 \pm 1.37 \& 4.33 \pm 1.64,1.67 \pm 0.84$ for fried chicken, all samples not detected for Shigella, respectively.9 E.coli (6\%) were isolated from samples represented 4(8\%),(2)O125:H2,(1)O143:H8and (1)O111:H1from chicken shawirma without addition, 3(6\%) O55: H2, O158:H3and O86a:H1 from chicken burger without addition, 2 (4\%) O142:H3, O26:H1from fried chicken, Also, 8(5.33\%) Coagulase positive Staphylococcus aureus were isolated from samples. Represented as 4(8\%) isolate from chicken shawirma without addition, $3(6 \%)$ from chicken burger without addition, 1(2\%) from fried chicken. 6(4\%) of Salmonella were isolated from Samples represented as 2(4\%) S. typhimurium and 1(2\%) S. enteritidis from shawirma without addition, 1(2\%)S. enteritidis and 1(2\%) S. Anatum from chicken burger without addition, 1(2\%) S.Kentucky from fried chicken. Isolates. Most of E.coli isolate sensitive for Colistin sulphate(10ug) and Nalidixic acid(10ug). St.aureus isolates sensitive to Ampicillin (10ug) and Vancomycin (15ug). Most of Salmonella isolate sensitive for Gentamycin (10ug), Colistin Sulphate(10ug) and Ceftriaxone.
\end{abstract}

Key words: Multi Drug resistant; Food-borne bacteria; ready to eat Chicken Meat.

\section{INTRODUCTION}

Foodborne illness is major health problem associated with ready to eat chicken

Corresponding author: Zeinab Ahmed

E-mail address: zeinabrenad@gmail.com

Present address: Reference Laboratory for Veterinary Quality Control on Poultry Production (RLQP), Animal Health Research Institute, Luxor, Egypt meat (Tabashsum et al., 2013). Multidrug resistant food borne microorganisms made the food safety situation more vulnerable in public health (Ahmed et al., 2011). Contamination of ready-to-eat foods persists through preparation and cooking due to the quality of raw materials (Dhama et al., 2013). Staphylococcus spp. contamination of excessive handling during preparation of the meal (Mensah et al., 2002). Foodborne illness is one of the significant public health 
problems worldwide Hereford, microbiological safety of food has become an important concern for consumers, various industries, and regulatory agencies (Bavisetty et al., 2018). Some microorganisms maintain their normal life functions in food and are used in food production, whereas others may cause food spoilage or foodborne diseases. as Salmonella spp., Campylobacter spp., Staphylococcus aureus, Escherichia coli and Shigella spp. (Saglam and Seker 2016). Approximately 1.8 million people died due to food-borne diarrheal infections each year in developing countries (WHO, 2007).Using of raw ingredients, insufficient workers hygiene, holding for long period, lead to contamination of food with pathogenic microorganisms (Gundogan et al., 2005). E. coli has become recognized as a serious foodborne pathogen that associated with diseases outbreaks including diarrhea, hemorrhagic colitis and the life-threatening hemolytic uremic syndrome in humans (Hussein, 2007). Consumption of ready-toeat products is thought to be the major cause of the Salmonella outbreaks (Thai et al., 2012). Shigella dysentriae contaminated water, food, and unhygienic environment like overpopulated area, malnourished people, and poor waste management area, usually it survives poorly outside human body (Wilson et al., 2005). Mould and mycotoxin contamination of food by feed ingredients (Trenholm et al., 2000). Bacteria and fungi are associated with Chicken meat spoilage acquired during slaughter, packaging, transportation or selling and handling include species of Salmonella, Shigella, Staphylococcus, Escherichia coli, Campylobacter, Penicillium and Cladosporin (Clarence et al., 2009). Antibiotics are used for control and treatment of bacterial diseases in poultry. There is growing scientific evidence that use of antibiotics in food animals leads to the development of resistant pathogenic bacteria that can reach humans through the food chain (Van Looveren et al., 2001). Recent reports have shown that different types of food and environmental sources harbor bacteria that are resistant to one or more antimicrobial drugs used in human or veterinary medicine and in food-producing animals (Anderson et al., 2003). Annual cost of treating infections caused by antibioticresistant bacteria is estimated to be $\$ 4$ to $\$ 5$ billion (McGowan 2001). Therefore, the present study was carried out for determination of APC, Coliform count \& Staphylococcus counts, Anaerobic count, Yeast count, Mould count and identification of St.aureus, entero pathogenic E. coli, Salmonella, Shigella for ready to chicken eat meat meals including chicken shawirma, chicken burger without addition, and fried chicken

\section{MATERIAL AND METHODS}

\section{Collection and transportation of samples:}

A total of 150 random samples of ready to eat chicken meat meals including, chicken shawirma, chicken burger each of them without addition, and fried chicken. (50 of each of product) were collected from different restaurants in Luxor City. Each sample was kept in a separate sterile plastic bag, put in an ice box then transferred to the laboratory under complete aseptic conditions without undue delay for bacteriological examination of samples.

\section{Preparation of samples (APHA 1992):}

Twenty five grams of the samples were taken under aseptic condition to sterile stomacher bag then $225 \mathrm{ml}$ sterile Buffer peptone water were added, the contents were homogenized at Stomacher for 2 minutes, the mixture was allowed to settled, for 5 minutes at room temperature. The contents were transferred into sterile flask, thoroughly mixed, $1 \mathrm{ml}$ was transferred into separate sterile test tube containing $9 \mathrm{ml}$ sterile slain, from which ten fold serial dilutions were prepared. 
3. Isolation and identification of foodborne bacteria:

The prepared samples were subjected to the following bacteriological examination: Determination of Aerobic Plate Count using ISO 4833-1:2013. Coliform count using ISO 4832 2006. Determination of total anaerobic bacterial count by Roberts et al., 1995. Determinations of Staphylococci count using ISO 6888-1-1999. Enumeration of yeast and Mould at $25^{\circ} \mathrm{C}$ for 5-7 days using ISO 21527-2:2008. Isolation of E.coli by ISO, 2001 and Varnam-Evans, 1991. The method for detection of S.aureus by ISO 6888-11999. The method for detection of Salmonella by ISO 65 79, 2002. The method for detection of Shigella using ISO 21567: 2004

\section{Identified serologically by using diagnostic sera:}

Serological diagnosis of Salmonella according to Kauffman - white scheme 1974 for determination of somatic antigen $(\mathrm{O})$ and Flagler antigen $(\mathrm{H})$ using DENKA SEIKEN CO®Japan). (Sero diagnosis of E.coli according to

\section{Antibiotic}

\section{sensitivity:}

Antibiotic sensitivity tests were done by using disc diffusion test following the method described by (WHO and CDC 2002). Were interpreted with the standard diameters of (NCCLS 2002) and were recorded as sensitive (S), intermediate (I) and resistant $(\mathrm{R})$. The following antibiotics will be used for disc diffusion test: Antibiotics will be used in Salmonella, E.coli, Shigella Amoxicillin-StreptomycinGentamycin-Nalidixic-Colistin sulphat Ceftriaxaon Ciprofloxacin- NeomycinSulphamethazol. Antibiotic used in Staph. Ampicillin- Clindamycin- Oxacillin Erythromycin- Gentamicin- VancomycinTetracycline-Chloramphenicol.

\section{RESULTS}

Table 1: Statistical analytical results of shawirma without addition in the examined samples $(\mathrm{n}=50)$.

\begin{tabular}{ccccccc}
\hline & APC & $\begin{array}{c}\text { Coliform } \\
\text { Count }\end{array}$ & $\begin{array}{c}\text { Staph. } \\
\text { Count }\end{array}$ & $\begin{array}{c}\text { Anaerobic } \\
\text { bacteria }\end{array}$ & $\begin{array}{c}\text { yeast } \\
\text { Count }\end{array}$ & Mould Count \\
\hline Minimum & $2.40 \times 10^{3}$ & $\leq 10$ & $\leq 10$ & $\leq 10$ & $\leq 10$ & $\leq 10$ \\
\hline Maximum & $7.80 \times 10^{4}$ & $8.30 \times 10^{3}$ & $2.00 \times 10$ & $2.00 \times 10$ & $4.00 \times 10$ & $3.00 \times 10$ \\
\hline Mean & $1.36 \times 10^{4}$ & $8.42 \times 10^{2}$ & 4.67 & 1.00 & 7.67 & 2.67 \\
\hline SE & $2.94 \times 10^{3}$ & $3.90 \times 10^{2}$ & 1.15 & 0.73 & 2.23 & 1.26 \\
\hline
\end{tabular}

Table 2: Statistical analytical results of burger without addition in the examined samples $(n=50)$.

\begin{tabular}{ccccccc}
\hline & APC & $\begin{array}{c}\text { Coliform } \\
\text { Count }\end{array}$ & $\begin{array}{c}\text { Staph. } \\
\text { Count }\end{array}$ & $\begin{array}{c}\text { Anaerobic } \\
\text { bacteria }\end{array}$ & $\begin{array}{c}\text { yeast } \\
\text { Count }\end{array}$ & Mould Count \\
\hline Minimum & $\leq 10$ & $\leq 10$ & $\leq 10$ & $\leq 10$ & $\leq 10$ & $\leq 10$ \\
\hline Maximum & $3.50 \times 10^{4}$ & $2.50 \times 10^{3}$ & $3.00 \times 10$ & $2.00 \times 10$ & $5.00 \times 10$ & $3.00 \times 10$ \\
\hline Mean & $5.58 \times 10^{3}$ & $3.34 \times 10^{2}$ & 2.33 & 1.00 & 8.33 & 2.67 \\
\hline SE & $1.16 \times 10^{3}$ & $9.82 \times 10$ & 1.24 & 0.75 & 2.40 & 1.26 \\
\hline
\end{tabular}


Table 3: Statistical analytical results of fried chicken in the examined samples $(n=50)$.

\begin{tabular}{ccccccc}
\hline & APC & $\begin{array}{c}\text { Coliform } \\
\text { Count }\end{array}$ & $\begin{array}{c}\text { Staph. } \\
\text { Count }\end{array}$ & $\begin{array}{c}\text { Anaerobic } \\
\text { bacteria }\end{array}$ & $\begin{array}{c}\text { yeast } \\
\text { Count }\end{array}$ & Mould count \\
\hline Minimum & $\leq 10$ & $\leq 10$ & $\leq 10$ & $\leq 10$ & $\leq 10$ & $\leq 10$ \\
\hline Maximum & $1.50 \times 10^{4}$ & $8.30 \times 10^{2}$ & $2.00 \times 10$ & $3.00 \times 10$ & $3.00 \times 10$ & $2.00 \times 10$ \\
\hline Mean & $4.62 \times 10^{3}$ & $1.53 \times 10^{2}$ & 1.33 & 3.00 & 4.33 & 1.67 \\
\hline SE & $7.42 \times 10^{2}$ & $4.85 \times 10$ & 0.79 & 1.37 & 1.64 & 0.84 \\
\hline
\end{tabular}

Table 4: The incidence of Staph, E. coli and Salmonella in samples.

\begin{tabular}{ccccc}
\hline Samples & $\begin{array}{c}\text { Number of } \\
\text { samples }\end{array}$ & $\begin{array}{c}\text { St.aureus } \\
\text { Isolates } \\
\mathbf{8 ( 5 . 3 3 \% )}\end{array}$ & $\begin{array}{c}\text { E. col isolates } \\
\mathbf{9 ( 6 \% )}\end{array}$ & $\begin{array}{c}\text { Salmonella } \\
\text { isolates 6(4\%) }\end{array}$ \\
\hline chicken shawirma & 50 & $4(8 \%)$ & $4(8 \%)$ & $3(6 \%)$ \\
\hline chicken burger & 50 & $3(6 \%)$ & $3(6 \%)$ & $2(4 \%)$ \\
\hline fried chicken & 50 & $1(2 \%)$ & $2(4 \%)$ & $1(2 \%)$ \\
\hline
\end{tabular}

Table 5: Serological identification of entero pathogenic E.coli in Samples.

\begin{tabular}{ccc}
\hline Samples & Serotyping of E.coli & $\%$ \\
\hline \multirow{2}{*}{ chicken shawirma } & O125:H2, O143 :H8 & $8 \%$ \\
\hline \multirow{2}{*}{ chicken burger } & O111: H1 & $6 \%$ \\
\hline Fried chicken & O 866 , $: \mathrm{H} 15: \mathrm{H} 3$ & $4 \%$ \\
\hline
\end{tabular}

Table 6: Serological identification of Salmonella in Samples.

\begin{tabular}{ccccc}
\hline \multirow{2}{*}{ Samples } & \multirow{2}{*}{ Identified Strains } & \multirow{2}{*}{ Group } & \multicolumn{2}{c}{ Antigenic structure } \\
\cline { 3 - 5 } & & & $\mathrm{O}$ & $\mathrm{H}$ \\
\hline chicken shawirma & Salmonella Typhimurium & $B$ & $1,4,5,12$ & $i: 1,2$ \\
\hline Fried chicken & Salmonella Kentucky & $\mathrm{C} 3$ & 8,20 & $\mathrm{i}: \mathrm{Z6}$ \\
\hline $\begin{array}{c}\text { chicken burger } \\
\text { shawirma }\end{array}$ & Salmonella Enteritidis & $\mathrm{D} 1$ & $1,9,12$ & $\mathrm{~g}, \mathrm{~m}$ \\
\hline chicken burger & Salmonella Anatum & $\mathrm{E} 1$ & 3,10 & $\mathrm{e}, \mathrm{h} ; 1,2$ \\
\hline
\end{tabular}

Table 7: Show the result of sensitivity test for Salmonella spp.

\begin{tabular}{|c|c|c|c|c|c|c|c|c|c|c|c|c|}
\hline \multirow[t]{2}{*}{ Antibiotic disc } & \multicolumn{3}{|c|}{$\begin{array}{c}\text { Salmonella } \\
\text { Typhimurium }\end{array}$} & \multicolumn{3}{|c|}{$\begin{array}{c}\text { Salmonella } \\
\text { Kentucky }\end{array}$} & \multicolumn{3}{|c|}{$\begin{array}{c}\text { Salmonella } \\
\text { Enteritidis }\end{array}$} & \multicolumn{3}{|c|}{$\begin{array}{c}\text { Salmonella } \\
\text { Anatum }\end{array}$} \\
\hline & $\mathbf{S}$ & $\mathbf{I}$ & $\mathbf{R}$ & $\mathbf{S}$ & $\mathbf{I}$ & $\mathbf{R}$ & $\mathbf{S}$ & $\mathbf{I}$ & $\mathbf{R}$ & $\mathbf{S}$ & $\mathbf{I}$ & $\mathbf{R}$ \\
\hline Gentamycin (10ug) & $\mathrm{S}$ & & & $\mathrm{S}$ & & & $\mathrm{S}$ & & & $\mathrm{S}$ & & \\
\hline Neomycin (30ug) & $\mathrm{S}$ & & & & & $\mathrm{R}$ & $\mathrm{S}$ & & & & & $\mathrm{R}$ \\
\hline Streptomycin(10mcg) & & & $\mathrm{R}$ & & & $\mathrm{R}$ & & $\mathrm{I}$ & & & & $\mathrm{R}$ \\
\hline Amoxicillin(25ug) & & & $\mathrm{R}$ & & & $\mathrm{R}$ & $\mathrm{S}$ & & & & & $\mathrm{R}$ \\
\hline Sulphamethoxazole(25) & & & $\mathrm{R}$ & & & $\mathrm{R}$ & $\mathrm{S}$ & & & & & $\mathrm{R}$ \\
\hline Colistin sulphate(10ug) & $\mathrm{S}$ & & & $\mathrm{S}$ & & & $\mathrm{S}$ & & & $\mathrm{S}$ & & \\
\hline Nalidixic & & & $\mathrm{R}$ & & $\mathrm{I}$ & & & & $\mathrm{R}$ & & $\mathrm{I}$ & \\
\hline Ciprofloxacin(5ug) & $\mathrm{S}$ & & & & & $\mathrm{R}$ & $\mathrm{S}$ & & & & & $\mathrm{R}$ \\
\hline Ceftriaxaon & $\mathrm{S}$ & & & & & $\mathrm{R}$ & $\mathrm{S}$ & & & $\mathrm{S}$ & & \\
\hline
\end{tabular}

Most isolate are sensitive for these antibiotic Gentamycin (10ug), Colistin sulphate (10ug)and Ceftriaxaon but Streptomycin is(R)and Nalidixic (I) 
Table 8: Show the result of sensitivity test for E.coli in Samples.

\begin{tabular}{|c|c|c|c|c|c|c|c|c|c|c|c|c|c|c|c|c|c|c|c|c|c|}
\hline \multirow{2}{*}{$\begin{array}{l}\text { E.Coli } \text { Isolates } \\
\text { Antibiotic disc }\end{array}$} & \multicolumn{3}{|c|}{$\mathrm{O} 142: \mathrm{H} 3$} & \multicolumn{3}{|c|}{ O158:H3 } & \multicolumn{3}{|c|}{ O86a:H1 } & \multicolumn{3}{|c|}{$\mathrm{O} 26: \mathrm{H} 1$} & \multicolumn{3}{|c|}{ O55:H7 } & \multicolumn{3}{|c|}{$\mathrm{O} 125: \mathrm{H} 2$} & \multicolumn{3}{|c|}{ O143:H8 } \\
\hline & $\mathbf{S}$ & I & $\mathbf{R}$ & $\mathbf{S}$ & I & $\mathbf{R}$ & $\mathbf{S}$ & I & $\mathbf{R}$ & $\mathbf{S}$ & $\mathbf{I}$ & $\mathbf{R}$ & $\mathbf{S}$ & I & $\mathbf{R}$ & $\mathbf{S}$ & I & $\mathbf{R}$ & $\mathbf{S}$ & I & $\mathbf{R}$ \\
\hline Gentamycin(10ug) & $\mathrm{S}$ & & & $\mathrm{S}$ & & & $\mathrm{S}$ & & & & $\mathrm{I}$ & & $\mathrm{S}$ & & & & & $\mathrm{R}$ & $\mathrm{S}$ & & \\
\hline Neomycin(30ug) & & & $\mathrm{R}$ & & & $\mathrm{R}$ & & & $\mathrm{R}$ & & & $\mathrm{R}$ & & & $\mathrm{R}$ & & & $\mathrm{R}$ & & & $\mathbf{R}$ \\
\hline Streptomycin(10ug) & & & $\mathrm{R}$ & & $\mathrm{I}$ & & & & $\mathrm{R}$ & & & $\mathrm{R}$ & & & $\mathrm{R}$ & & & $\mathrm{R}$ & & & $\mathbf{R}$ \\
\hline Amoxicillin(25ug) & & $\mathrm{I}$ & & & & $\mathrm{R}$ & & & $\mathrm{R}$ & & & $\mathrm{R}$ & & $\mathrm{I}$ & & & & $\mathrm{R}$ & & & $\mathbf{R}$ \\
\hline $\begin{array}{c}\text { Sulphamethoxazole } \\
\text { (25ug }\end{array}$ & $\mathrm{S}$ & & & & & $\mathrm{R}$ & & & $\mathrm{R}$ & & & $\mathrm{R}$ & & & $\mathrm{R}$ & $\mathrm{S}$ & & & & & $\mathbf{R}$ \\
\hline Colistin sulphate(10ug) & $\mathrm{S}$ & & & & & $\mathrm{R}$ & $\mathrm{S}$ & & & $\mathrm{S}$ & & & $\mathrm{S}$ & & & $\mathrm{S}$ & & & $\mathrm{S}$ & & \\
\hline Ciprofloxacin(5ug) & $\mathrm{S}$ & & & & & $\mathrm{R}$ & & & $\mathrm{R}$ & & & $\mathrm{R}$ & & & $\mathrm{R}$ & $\mathrm{S}$ & & & & & $\mathbf{R}$ \\
\hline Nalidixic acid(10ug) & $\mathrm{S}$ & & & & $\mathrm{I}$ & & $\mathrm{S}$ & & & $\mathrm{S}$ & & & $\mathrm{S}$ & & & & & $\mathrm{R}$ & $\mathrm{S}$ & & \\
\hline Cefirioxacin & $\mathrm{S}$ & & & & & $\mathrm{S}$ & & $\mathrm{I}$ & & & & $\mathrm{R}$ & $\mathrm{S}$ & & & $\mathrm{S}$ & & & & & $\mathbf{R}$ \\
\hline
\end{tabular}

Most of E.coli isolate sensitive for Colistin sulphate(10ug) and Nalidixic acid(10ug)

Table 9: Show the result of sensitivity test for Staphylococcus aureus in Samples.

\begin{tabular}{|c|c|c|c|c|c|c|c|c|c|c|c|c|}
\hline Antibiotic disc & & 1 & & & 2 & & & 3 & & & & \\
\hline & $\mathbf{S}$ & $\mathbf{I}$ & $\mathbf{R}$ & $\mathbf{S}$ & I & $\overline{\mathbf{R}}$ & $\mathbf{S}$ & $\mathbf{I}$ & $\mathbf{R}$ & $\mathbf{S}$ & $\mathbf{I}$ & $\mathbf{R}$ \\
\hline Erythromycin E (15ug) & $\mathrm{S}$ & & & $\mathrm{S}$ & & & & $\mathrm{I}$ & & $\mathrm{S}$ & & \\
\hline Vancomycin VA (15ug) & $\mathrm{S}$ & & & $\mathrm{S}$ & & & $\mathrm{S}$ & & & $\mathrm{S}$ & & \\
\hline Tetracycline T(30ug) & & & $\mathrm{R}$ & & & $\mathrm{R}$ & & & $\mathrm{R}$ & & & $\mathrm{R}$ \\
\hline Ampicillin AM (10ug) & $\mathrm{S}$ & & & $\mathrm{S}$ & & & $\mathrm{S}$ & & & & $\mathrm{I}$ & \\
\hline Oxacillin OX(1ug) & & & $\mathrm{R}$ & & & $\mathrm{R}$ & & & $\mathrm{R}$ & & & $\mathrm{R}$ \\
\hline Gentamycin Cn (10ug) & & & $\mathrm{R}$ & & & $\mathrm{R}$ & & & $\mathrm{R}$ & & $\mathrm{I}$ & \\
\hline Clindamycin(10ug) & & & $\mathrm{R}$ & & & $\mathrm{R}$ & & & $\mathrm{R}$ & & & $\mathrm{R}$ \\
\hline Chlroamphenicol(30ug) & & & $\mathrm{R}$ & & & $\mathrm{R}$ & & & $\mathrm{R}$ & & & $\bar{R}$ \\
\hline
\end{tabular}

Most of isolate are sensitive to Ampicillin AM (10ug), Erythromycin (15 ug) and Vancomycin VA (15ug) and Gentamycin, Clindamycin and Chloramphenicol are (R)

\section{DISCUSSION}

The total aerobic plate count is important for evaluation of sanitary condition of ready to eat chicken meat. Limits suggested for total aerobic bacterial count in ready to eat chicken meat range not less than $10^{4}$ microbes /g (ISO 4833-1:2013). Accordingly the high bacterial count of some examined samples may be attributed to neglected sanitary measures during their handling, preparation and serving. The mean values of $A P C$ for chicken shawirma without addition, burger without addition and fried chicken were $1.36 \times 10^{2}(\mathrm{cfu} / \mathrm{g}), 5.58 \times 10^{3}(\mathrm{cfu} / \mathrm{g})$ and $4.62 \times 10^{3}(\mathrm{cfu} / \mathrm{g})$. These results were Nearly (El Taher-Amna 2009) who found that APC $5.38 \times 10^{3}(\mathrm{cfu} / \mathrm{g})$ from burger. The mean values of Coliform for chicken shawirma without addition, burger without addition and fried chicken were $8.42 \times 10^{2}(\mathrm{cfu} / \mathrm{g})$,
$3.34 \times 10^{2}(\mathrm{cfu} / \mathrm{g}), 1.53 \times 10^{2}(\mathrm{cfu} / \mathrm{g})$. The current results lower than (El-Rayes 2008) who found that the mean value of Coliform was $3.8 \times 10^{3} / \mathrm{g}$ in ready to eat chicken meat and agree with (Saad et al., 2011) who found that the mean value of Coliform was $5.17 \times 10^{2}$ in the examined samples. The mean values of Staph Count for chicken shawirma without addition, burger without addition and fried chicken were $4.67(\mathrm{cfu} / \mathrm{g})$, $2.33(\mathrm{cfu} / \mathrm{g}), 1.33$ (cfu/g). The low incidence of Staph.aureus attributed to exposure of those products to high temperature during processing (Amal, 2004). The mean values of Yeast and Mould for chicken shawirma without addition, burger without addition and fried chicken were 7.67, 2.67 (cfu/g) and 8.33, $2.67(\mathrm{cfu} / \mathrm{g})$ and 4.33, $1.67(\mathrm{cfu} / \mathrm{g})$. respectively Mould and yeast contamination usually occurred due to handling, deboning, processing, packing and washing with 
polluted water and may due to dust, flies, air, workers, equipment and fluctuation of temperature during transportation and storage(Farghaly, 1998). Salmonella is responsible for disease in humans. It has been the leading cause of many outbreaks and infections around the world and is considered as one of the major causes of human gastroenteritis (Rasschaert et al., 2005).In these result isolates were 6 (4\%) Salmonella from 150 examined ready to eat chicken meat samples. The serological examination of identified Salmonella isolates showed that $S$. typhimurium, $S$. enteritidis, S. Anatum and S.Kentucky were detected. These results was higher than (AlMutairi 2011)and less than( Shaltout et al., 2013) and (Harakeh et al., 2005) which reported prevalence of Salmonella $7.4 \%$. Most isolate of Salmonellae are sensitive for Gentamycin (10ug), Colistin sulphate (10ug), Ceftriaxone which agree with (Gomba et al., 2016), (Lamas et al., 2016) and (Arora et al., 2015) and dis agree with (Stopforth et al., 2006) who said most of isolate of Salmonellae are resist for Ceftriaxone. The presence of Staph aureus in heat treated food may be due to its contamination from food handlers, inadequate cleaned equipment or post processing contamination (Duffy et al., 2000). 8(5.33\%) isolates of St.aureus were isolated from 150 examined these results was higher than those obtained by (Shafizi et al., 2016) who recorded Staph. aureus was $2.3 \%$ and less than (Ali-Sohaila and AbdElaziz-Doaa, 2011) who recorded Staph. aureus was $30 \%$ and agree with, (DiazLopes et al., 2011) who recorded $6.3 \%$ of Staph. aureus. Cooking plays a great role in killing of most of these microorganisms but not all. Presences of heat resistance toxins from some of these bacteria represent a great public health hazard especially in places with great groups of people receiving this food. Also, post cooking recontamination when holding of such meals for a period until serving in unhygienic condition especially at room temperature or insufficient reheating represent of major public health hazard. Food handlers are important source of Staphylococcal Spp for food contamination in restaurants and food outlets (Colombari et al., 2007). As a result there is an increased risk of pathogens surviving and transferring not only by crosscontamination, but also by undercooking as observed in this kind of fast-food industry (Nimri-Laila et al., 2014). Most of isolate sensitive for Colistin sulphate and Nalidixic acid. The result agree with (Abdul Matin et al., 2017). E.coli play an important role as human pathogens, which give rise to gastroenteritis outbreaks, severe diarrhea in infants, coli-bacillosis in adults, meningitis and enteritis (Youssef et al., 1992). 9(6\%) isolates of E.coli were isolated from 150 examined ready to eat chicken meat samples. O125:H2, O143:H8 and O111:H1 from chicken shawirma without addition, O55: H2, O158:H3, O86a:H1 from chicken burger without addition, O142:H3, O26:H1. Isolates were positive for fried chicken. These results agreement with (Mohammed et al., 2014), O55:H2 these results nearly in agreement with, (DíazSánchez et al. 2012). Most isolate of E.coli were sensitive for Colistin sulphate (10ug) which agree with (ElSukhon et al., 2002) and dis agree with (Obeng et al., 2012) who said most of isolate of E.coli are resist for Nalidixic acid.

\section{CONCLUSION}

This study indicated that RTE Chicken meats are often contaminated with APC, Coliform, Staphylococcus, Yeast, Mould Counts and Staph. aureus, Salmonella and E.coli. There is need for the relevant local authorities to ensure that the food sold to consumers in fast food restaurants is safe, wholesome and fit for human consumption in order to prevent outbreaks of food-borne illnesses. Addition of vegetables lead to increase contamination and count of microorganism, so the samples without addition of vegetables low in contamination and count of microorganism, Shawirma is more contaminated product because low in cooking. Cooking plays a great role in 
killing of most of these microorganisms but not all. After Cooking may occur recontamination when holding of such meals for a period until serving in unhygienic condition especially at room temperature or insufficient reheating represent of major public health hazard. Food handlers, Utensils, bad Quality packaging and bad environment are important source of the contamination There should be In addition Procurement of raw materials of the best possible microbiological quality, Prevention of undue contamination of fast foods prior to processing, Regular training to food handlers in all aspects of food hygiene and safety, Quality packaging to keep foods fresh and get rid of health risk factors, Adequate storage, ideal transportation, and hygienic handling to finished product, Microwave oven treatment prior to serving to consumption, Ensuring good quality raw materials, adequate lethality treatment, and effective sanitation of both the equipment and processing environment.

\section{REFERENCES}

Abdul Matin, M.D.; Ariful, I. and Minara, M.K. (2017): prevalence of Colibacillosis in chicken in greater Mymensingh district of Bangladesh Md. Veterinary World, 10(1):29- 33.

Ahmed, T.M. (2011): Entrepreneurs of the Streets: an Analytical Work on the Street Food Vendors of Dhaka City; International Journal of Business and Management, Vol.4, No.2, Feb.

Ali-Sohaila, F. and Abd-Alaziz-Doaa, M. (2011): Incidence of enter toxigenic Staphylococcus aureus in some readyto-eat meat in Assuit City with special reference to Methicillin Resistant Staphylococcus aureus strains. Assiut Veterinary Medical Journal 57(129): 95- 106.

Al-Mutairi, MF. (2011): The incidence of entero bacteriaceae causing food poisoning in some meat products. Advance Journal of Food Science and Technology, 3(2): 116-121.
Amal A.S. (2004): Trials for inhibition of some food poisoning microorganisms in meat products. Ph.D. Thesis (Meat Hygiene), Faculty of Veterinary Medicine, Cairo Univ ersity, Giza, Egypt.

American Public Health Association"APHA (1992): Compendium of Methods for the Microbiological examination of Foods. 3 rd Ed. (carl, v). The American Public Health Association, DC.

Anderson, AD.; Nelson, JM.; Rossiter, S. and Angulo, FJ. (2003): Public health consequences of use of antimicrobial agents in food animals in the United States. Microb. Drug. Resist. 9: 373379

Arora, D.; Kumar, S.; Jindal, N.; Narang, G.; Kapoor, P.K. and Mahajan, N.K. (2002): prevalence and epidemiology of Salmonella enteric a serovar Gallinarum from poultry in some parts of Haryana, India, veterinary world 8(11); 1300-1304.

Bavisetty, SCB.; Vu, HTK; Benjakul, S. and Vongkamjan, K. (2018): Rapid pathogen detection tools in seafood safety. Curr Opin Food Sci 20: 92-99.

Clarence, SY.; Obinna, CN. and Shalom, NC. (2009): Assessment of bacteriological quality of ready to eat food (Meat pie) in Benin Citymetropolis, Nigeria. Afr. J. Microbial. 50: 150-153.

Colombari, V.; Mayer, M.D.B. and Laicini, Z.M. (2007): Foodborne outbreak caused by Staphylococcus aureus phenotypic and genotypic characterization of strains of food and human sources. Journal of Food Protection 70: 489-493.

Dhama, KS.; Rajagunalan, R.; Tiwari, AK.; Verma and SDSingh (2013): Foodborne pathogens of poultry having public health significance Poultry World, Feb. Issue, pp: 8-12.

Díaz-Sánchez, S.; Sánchez, S.; Sánchez, M.; Herrera-León, S.; Hanning, I. and Vidal, D. (2012): Detection and 
characterization of Shiga toxinproducing Escherichia coli in game meat and ready-to-eat meat products. International Journal of Food Microbiology, 160: 179-182.

Duffy, G.; Kilbride, B.; Sherdian, J.J.; Blair, I.S. and McDowell, D.A. (2000): A membrane-immune-fluoresce validity staining technique for the detection of Salmonella species from fresh and processed meat samples. J. appl. Microbiol. 1, 89(4): 587-594.

El-Rayes, A.M.A. (2008): Incidence of pathogenic Escherichia coli in fast foods. M.V.Sc. Thesis, Fac. Vet. Med, Benha University.

El-Sukhon, S.N.; Musa, A. and Al-Atter, M. (2002): Studies on the bacterial etiology of airs acculitis of broilers in northern and middle Jordan with special reference to Escherichia coli, Ornithobacterium rhinotracheale, and Bordetella avium Diseases 46(3): 605610.

EL-Taher-Amna, M. (2009): Impact of temperature abuse on safety of food offered in University Student Restaurant M.V.Sc. Thesis, Meat hygiene, Fac. of Vet. Med. Benha Univ.

Farghaly, R.M. (1998): Some studies on the aflatoxin producing aspergilla in meat cold stores. Assuit Med. J., 31: 111120.Vet.

Gomba, A.; Chidamba, L. and Korsten L. (2016): Antimicrobial Resistance profile of Salmonella Spp. Foodborne pathogens and Diseases. Vol. 13, No. 9,pp: 495-501

Gundogan, N.; Citak, S.; Yucel, N. and Devren, A. (2005): A note on the incidence and antibiotic resistance of Staphylococcus aureus isolated from meat and chicken samples. Meat Science, 69: 807-810.

Harakeh, S.; Yassine, H.; Gharios, M.; Barbour, E.; Hajjar, S.; El-Fadel, M.; Toufeili, I. and Tannous, R. (2005): Isolation, molecular characterization and antimicrobial resistance patterns of
Salmonella and Escherichia coli isolates from meat-based fast food in Lebanon. Science of the Total Environment, 341(1-3): 33-44.

Hussein, HS. (2007): Prevalence and pathogenicity of Shiga toxin producing Escherichia coli in beef cattle and their products. Journal of Animal Science, 85 (13): 63-72.

ISO (2001): Microbiology of food, animal feeding stuffs. Horizontal method for the enumeration of $\beta$ - glucuronidas Positive E-Coli. Part 2: Colony Count Technique at $44^{\circ} \mathrm{c}$ using 5bromo-4chloro-3-indolyl $\beta$-Dglucuronide. 16649-2.

ISO 21527 (2008): Microbiology of food and animal feeding stuffs Horizontal method for the enumeration of yeasts and moulds - Part 2: Colony count technique in products with water activity less than or equal to 0,95 .

ISO 21567 (2004): International Organization for Standardization Microbiology of foods and animal feeding stuffs- Horizontal method for the detection of Shigella species. Premie're edition 01-11-2004.

ISO 4832 (2006): Horizontal method for the enumeration of coliforms - Colony count technique.

ISO 4833 (2013): Horizontal method for the enumeration of microorganisms Colony count technique in at $30 \mathrm{C}^{\circ}$ by the pour plat technique.

ISO 6579 (2002): (E) 4rd ed. Microbiology General guidance on methods for the detection of Salmonella, International Organization for Standardization, Genève, Switzerland.

ISO 6888 (1999): Microbiology of food and animal feeding stuffs - Horizontal method for the enumeration of Staphylococcus aureus and other species - Part 1.

Lamas, A.I.C.; Fernandez, No.; Miranda, J.M.; Vazquez, B.; Cepeda, A.; and Franco, C.M. (2016): Prevalence, Molecular Characterization and Antimicrobial Resistance of 
Salmonella Serovars Isolated From Northwestern Spanish Broiler Flocks, (1) $26 ; 83$.

McGowan, JE. (2001): Economic impact of antimicrobial resistance. Emerg. Infect. Dis., 7: 286-292. Merchant IA and RA Packer, 1967. Veterinary Bacteriology and Virology. 7th edn. The Iowa University Press, Ames, Iowa, USA. pp: 286-306.

Mensalhel, C.K.B.; Peters, M.T.; Gharbia, S.E.; Logan, J.M.J. and Arnold, C. (2002): Towards the development of a DNA-sequence based approach to serotyping of Salmonella enterica. BioMed Central Microbiology 4 (31), doi: 10.1186/1471-2180-4-31.

Mohammed, MA.; Sallam, KI.; Eldaly, EAZ.; Ahdy, AM. and Tamura, T. (2014): Occurrence, serotypes and virulence genes of non-O157 Shiga toxin producing Escherichia coli in fresh beef, ground beef, and beef burger. Food Control, 37: 182-187.

NCCLS (2002): Performance Standards for Antimicrobial disc and Dilution Susceptibility test for Bacterial Isolated From Animals , Approved standard $2^{\text {nd }}$ Edition M31- A2 22(6).

Nimri-Laila, Abu AL-Dahab-Fatina and Batchoun, R. (2014): Foodborne bacterial pathogens recovered from contaminated Shawirma meat in northern Jordan. Journal of infection in developing countries 8(11):1407-1414

Obeng, AS.; Rickard, H.; Ndi, O., Sexton, M. and Barton, M. (2012): Antibiotic resistance, phylogenetic grouping and virulence potential of Escherichia coli isolated from the faeces of intensively farmed and free range poultry. Vet. Microbial. 154, 305 - 315.

Rasschaert, G.; Houf, K.; Imberechts, H.; Grijspeerdt, K.; De Zutter, L. and Heyndrickx M. (2005): Comparison of five repetitive-sequence-based PCR typing methods for molecular discrimination of Salmonella enterica isolates. Journal of Clinical Microbiology, 43 (8): 3615-3623.
Roberts, T.A.; Baired parker, A.C. and Tompkin, R.B. (1995): eds. Microorganisms in foods 5: Microbiological specifications of food pathogens.1 st Ed, BlackieAcadimic \&Professional, London, UK, pp. 217264.

Saad, M.S.; Hemat, M.I. and Enas, A.M.A. (2011): Microbial and chemical evaluation of fast foods. J. Benha vet. Med. S.E (1):44-51.

Saglam, D. and Seker, E. (2016): Gida kaynaklı bakteriyel patojenler. KocatepeVet J 9: 105-113.

Shafizi, A.W.; Mohammad Ridzuan, M.S.; Ubong, A.; New, C.Y.; Mohhiddin, O.; Toh, P.S.; Chai, L.C. and Son, R. (2016): Assessing Staphylococcus aureus in ready to eat (RTE) food and risk assessment of food premises in Putrajaya. International Food Research Journal 23(4): 1761 -1766.

Shaltout, F.A.; Amani, M. Salem; Mahmoud, A.H. and Abd, KA. (2013): Bacterial Aspect of Cooked Meat and Edible Offal at Street Vendors Level. Benha Veterinary Medical Journal, 24(1): 320-328.

Stopforth, J.D.; Lopes, M.; Shultz, J.E.; Miksch, R.R. and Samadpour, M. (2006): Location of Bung Bagging during Beef Slaughter Influences the Potential for Spreading Pathogen Contamination on Beef Carcasses. J Food prot. V (69): 1452- 1455.

Tabashusm, Karma M.; Rositto, PV.; Morgante, RA. and Cullor, JS. (2013): Enterotoxin production by Staphylococcus aureus isolated from mastitis cows. J Food Prot 66: 16931696.

Thai, TH.; Hirai, T.; Lan, NT. and Yamaguchi, R. (2012): Antibiotic resistance profiles of Salmonella serovars isolated from retail pork and chicken meat in North Vietnam. International Journal of Food Microbiology, 156: 147-151. 
Trenholm, HL.; Charmley, LL. and PreLusk, $Y$. (2000): Mycotoxin binding agents: An Update Farming today.; 1: P. 11.

Van Looveren, M.; Daube, G.; De Zutter, L.; Dumont, JM.; Lammens, C.; Wijdooghe, P.; Vandamme, M.; Jouret, M.; Cornelis, $M$. and Goossens, H. (2001): Antimicrobial susceptibilities of Campylobacter strains isolated from food animals in Belgium. J. Antimicrob. Chemother., 48: 235-240.

Varnum, A.H. and Evans, M.G. (1991): Foodborne pathogens. An illustrated text chapter 13, pp 267 England, Wolfe publishing Ltd. ISBN 07234:1521-8.
WHO (2007): Food safety and food borne illness World Health Organization, Geneva ("Forging links between agriculture and Health" CGIAR on Agriculture and Health Meeting in WHO/HQ). World Health Organization.

WHO. and CDC. (2002): Manual for the Laboratory Identification and Antimicrobial Susceptibility Testing of Bacterial Pathogens of Public Health Importance in the Developing World.

Wilson, G.; Easow, JM.; Mukhopadhyay, C. and Shivananda, PG. (2005): Isolation and antimicrobial susceptibility of Shigella from patients with acute gastroenteritis in western Nepal. India J Med Res. 123: 145-50

\section{الكثف عن البكتيريا المقاومة للمضادات الحيوية في لحوم الدواجن الجاهزة للاستهلاك زينب /حمد محد /حد ، شيياء النجار طاهر \\ E-mail: zeinabrenad@gmail.com Assiut University web-site: www.aun.edu.eg}

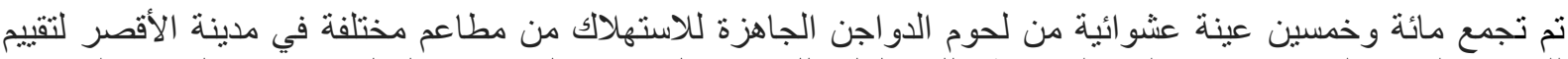

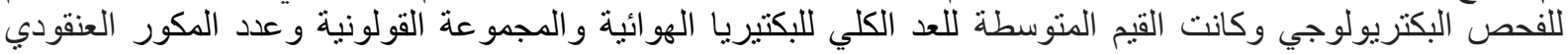

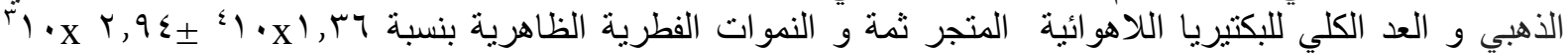
藏 إضافة و g

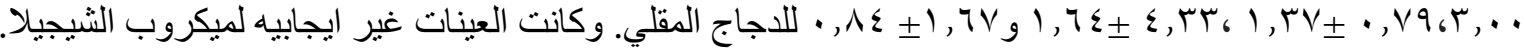

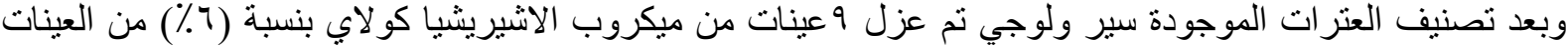

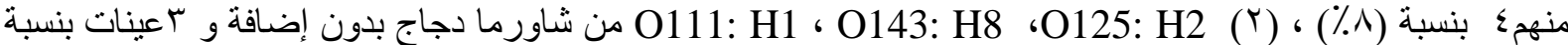

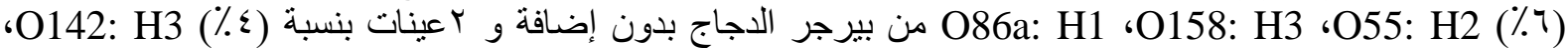
O26: H1

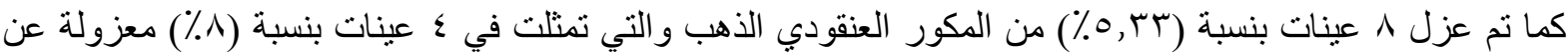

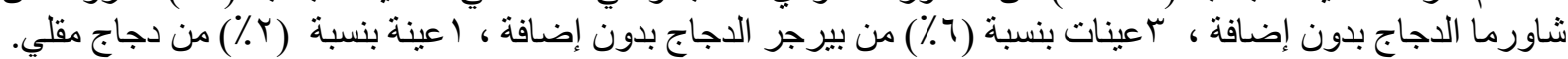

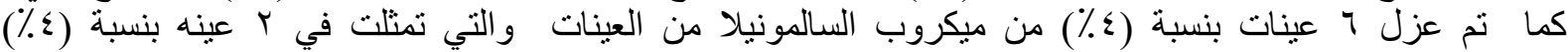

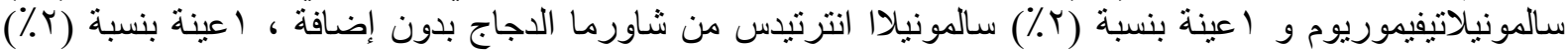

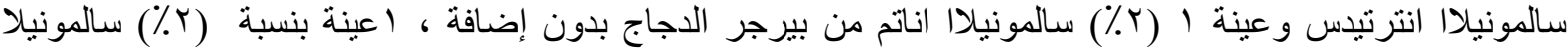
كينتاكي من الدجاج المقلي.

وجد انه معظم ميكروب الاشيريشيا كولاي حساسة للمضادات الحيوية الاتيه كبريتات الكوليستين (• (1 ميكروغرام)

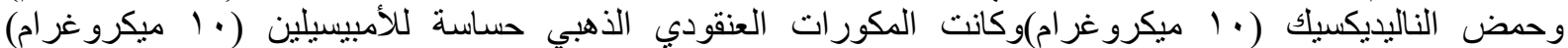

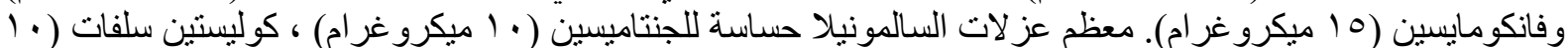
ميكرو غر ام) و سيفترياكسون (هنيكرو امنا. 